\title{
CYPRUS: ANEMONE AND MYRTLE1
}

\section{Wisam Mansour, Eastern Mediterranean University, Famagusta, North Cyprus}

Spring after spring, beautiful nature in the land of Aphrodite softly sings the melodious, exotic, and sad myths of ancient Cyprus.

How many a tourist or visitor venturing through the Aden-like landscape decked with the delicate jewels of Persephone, would tune his ears to the whispering sound of the anemones and marjoram telling their eternal tale of passion, love and suffering? How many would, with their sharp eyes, notice the pearl-like tears of the myrtle, confirming with the language of silence, the whispered tales of the anemones and the marjoram. Pink and white cyclamen, elecampane, sedges, basil, balsam, thyme and rosemary are the everlasting audiences and witnesses to the ancient myths that were once enacted around Salamis, Karpass, Amathus, Paphos, to mention but a few names; myths that are still carried around with the gentle sighs of the breeze.

One of these myths, still narrated every spring with the sighs of the breeze and the mime of the anemone and the myrtle, is that of Pygmalion and his issue.

With a heart beating like the fluttering wings of the larks and sparrows descending from the heights of Kantara and Mount Olympus, young Pygmalion beseeched Aphrodite to send him a wife similar to the beautiful ivory statue he had made:2

If that you goddes can all things give, then let my wife (I pray)

(He durst not say bee yoon same wench of ivory, but) be leeke My wench of ivory

(Ovid, Metamorphoses X.298)

Aphrodite was very quick in answering Pygmalion's prayers: upon arriving home, he embraced his statue, and to his great pleasure the perfect woman he carved from ivory was throbbing with life and with warmth:

...In her body streyght a warmnesse seemed to spread.

He put his mouth againe to hers, and on her brest did lay his hand. The ivory wexed soft: and putting quyght away All hardnesse, yeelded underneathe his fingars,

(Ovid, Metamorphoses X.307)

1 Akroterion is pleased to publish this short essay as an example of the creative writing which can still be inspired by the Roman poet Ovid, who made all of the Greek world his own through his songs. See Introduction in the recent publication of a volume of essays discussing Ovidian influences on literature and an from the Middle Ages to the twentieth century: Martindale, $\mathrm{C}$ (ed.) 1988, Ovid Renewed (Cambridge: Cambridge University Press).

2 To complement the lyrical style of this "song of praise to Cyprus" the author has elected to quote from an old English translation of Ovid's Metamorphoses: Ovid [1567] 1965. Metamorphosis. The Arthur Golding Translation (ed. John Frederick Nims), New York: Macmillan. 
The young artist who once despised all women was head over neels in love with his bride. Cyprus with its sparrows, larks, and wild life was a witness to their love-making. This exotic and strange encounter yielded a child after whom the city of Paphos was named.

That when the moone with fulsum lyght nyne tymes her course had go,

This ladye was delivered of a sun that Paphus hyght,

Of whom the Iland takes that name. Of him was borne a knyght

Called Cinyras who (had he no issue) surely might

Of all men underneath the sun beene thought the happyest wyght.

(Ovid, Metamorphoses X.322)

But the gods move in mysterious ways, and all the happiness they confirmed on Pygmalion was transformed into misery and shame for his grandson, king Cinyras. The ill-fated king fathered a beautiful girl he named Myrrha. And like Pygmalion who fell in love with what he had made, Myrrha fell in love with the one who authored her life: she fell in love with her father. This unlawful passion for her father tormented her. Under the pain of suffering she thought of leaving Cyprus, and she attempted a suicide:

...Were not Cinyras my father than, Iwis

I myght obtaine to lye with him. But now bycause he is

Myne owne, he cannot bee myne owne.

And if I wist I therby this wickednesse myght shunne, I would forsake my native soyle and farre from Cyprys runne.

(Ovid, Metamorphoses X.374)

But eventually, through the aid of her nurse, and under the cover of the night she managed to creep into her father's bed and do the thing that, in Ovid's opinion, dimmed the faces of the moon and the sun alike. When Cinyras, after some repeated nights of love-making to that mysterious young girl, realized the enormity of his heinous deed, he attempted to kill his treacherous daughter. But Myrrha escaped under the cover of night; and fleeing from Cyprus, wandered into far lands until she arrived in Yemen.

Away ran Myrrha, and by means of darknesse of the nyght She was delivered from the death: and straying in the broade Datebearing feeldes of Arabye, shee through Panchaya yode, And wandring full nyne moonethes at length she rested beeing tyrde In Saba land

(Ovid, Metamorphoses X.546)

When the time came for her to give birth Myrrha, in her shame, misery and suffering, begged Zeus to show compassion to her child and to give her the punishment she deserved for the sins she had committed. Zeus responded to her prayers, and instantly Myrtha was metamorphosed into a myrtle tree, and out of her bark the beautiful Adonis was delivered by the help of Lucina, a water nymph: 
Lucina to this wofull tree came gently downe, and layd

Her hand theron, and speaking woordes of ease the midwife played.

The tree did cranye, and the bark deviding made away,

And yeelded out the chyld alyve, which cryde and wayld streyght way.

The waternymphes upon the soft sweete hearbes the chyld did lay,

And bathed him with his mothers teares. His face was such as spyght

Must needes have praysd. For such he was in all condicions right,

As are the naked Cupids that are in tables picturde bee.

(Ovid, Metamorphoses X.585)

Time passed and the child became a beautiful lad. And by a quirk of chance, Aphrodite was injured by one of her son's arrows, while she was looking at Adonis. Cupid's wound inflamed her heart with love for the Cypriot youth. Henceforth the goddess neglected Olympus and everything celestial, choosing to roam the island of Cyprus with her young lover, enjoying the bliss of love beneath the hills, along the flowery valleys and on the golden beaches:

Yea even from heaven she did absteyne, Shee lovd Adonis more Than heaven. To him she clinged ay, and bare him companye.

(Ovid, Metamorphoses X.614)

Fate willed it that Aphrodite should leave her young lover for a short time, but not without admonishing him against hunting the wild beasts. Adonis, a typical youth, did not heed the advice of his goddess and mistress. He attempted to hunt down a wild boar. He shot the beast and injured it. The injured beast went for the young hunter and gored him. Adonis fell dead, his blood spattering the ground. All this happened while the unfortunate Aphrodite was on her way back to Cyprus. When she saw her lover dying in front of her eyes, she was overwhelmed with sadness; she tore her hair, she beat her breast, but to no avail, her lover had perished:

Dame Venus in her chariot drawen with swannes was scarce arrived At Cyprus, when she knew a farre the sygh of him depryved Of lyfe. She turned her Cygnets backe and when she from the skye Beehilld him dead, and in his blood beweltred for to lye:

Shee leaped downe, and tare at once hir garments from her brist, And rent her heare, and beate upon her stomach with her fist,

(Ovid, Metamorphoses X.841)

To immortalize her lover, from the sanguine red gore of his veins, she caused the anemone to spring up all through the island; and from her own delicate pink ichor, dripping from the wounds caused by the thorny bushes where her lover lay dead, marjoram and cyclamen sprang.

[Aphrodite said:] ... Of my greefe remembrance shall remayne (Adonis) whyle the world doth last. From yeere to yeere shall growe A thing that of my heavinesse and of thy death shall showe The lively likenesse. In a flowre thy blood I will bestowe.

(Ovid, Metamorphoses X.848) 
And thus the curtain falls on those Cypriot mythical figures who were fathered by a talented, skilful artist upon an ivory statue that was made by him. These fantasy figures have departed long ago, but they left Cyprus a legacy of tender and sad stories; and an everlasting heritage of lovely flowers and plants that deck this beautiful Mediterranean island: myrtle, anemone, marjoram and cyclamen, all are Cyprus' eternal children telling the tales of the past, while dancing with the breeze for the delight of all with sharp ears and keen eyes. 